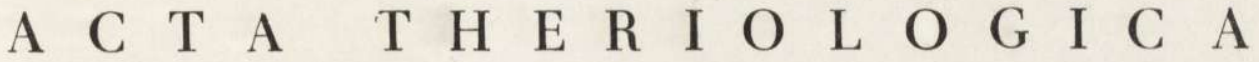

VOL. XII, 39: 545-553.

BIAŁOWIEŻA

30.XII.1967

\author{
Michalina P U CEK
}

\section{Changes in the Weight of Some Internal Organs of Micromammalia Due to Fixing}

\author{
[With 2 Figs. \& 2 Tables]
}

\begin{abstract}
Fixing the internal organs of Micromammalia in alcohol causes a reduction in their weight, the brain losing an average of $42 \%$, kidneys and spleen $35 \%$, liver and heart over $28 \%$. Reduction in weight of different organs is connected with lenght of fixing and number of times the fixing fluid is changed. The effect of $4 \%$ formalin on organs varies. The brain and kidneys markedly increase in weight during the first phase of fixing, then this increase is reduced but never falls below the fresh mass weight, as is observed in the case of the spleen or liver, while the heart does not exhibit significant changes in weight. The great variability in weight of organs fixed in alcohol and formalin makes it impossible to use such material for studies on variations in weight and weight proportions of internal organs.
\end{abstract}

\section{INTRODUCTION}

A considerable amount of technical difficulty is encountered in examination of internal organs. Different methods of dissection, the interval between animal's death and fixing of the organs and amount of blood lost may all exert an important influence on the absolute weight of ograns (W ebster \& Liljegren, 1949). The matter becoms even more complicated if, as is often done, material previously fixed is used for studies on variation in weight and weight proportions of internal organs.

Every fixing process is connected with changes in weight and volume of the organ which in turn depend on the kind and concentration of the fixing agent, length of fixing time and also on physical and chemical properties of the fixing fluid and fixed organ. For instance the fixing action of alcohol consists chiefly in extracting water, and as a result the tissue shrinks and the weight of the fixed organs decreases by several percent. In formalin, on the other hand, organs generally swell and increase their weight.

The percentage by which the weight of organs is either increased or decreased has not as yet been accurately determined. Experiments made for this purpose, 
mainly using the brains of larger animals such as pigs, sheep, rabbits and dogs, reveal different values. M a r s a l, for instance, calculated a weight increase of $7.24 \%$ for brains fixed in formalin, Brock a $30 \%$, Bisch off $25 \%$, Vierord $40 \%$ (cited after K etz, 1952/53). K etz (l. c.) on the other hand states that fixing a brain in $10 \%$ formalin causes an average increase in its weight of $7.9 \%$. This author records weight losses of $2.5 \%, 8.4 \%$ and $1.4 \%$ for three brains fixed in alcohol.

On this account different authors arbitrarily asume different indices of increase or decrease in weight of organs and add them to the weight after fixing in order to obtain the weight of the fresh mass of the organ (Kost y ra, 1960). L u s k \& Pokorny (1964) state that the body weight of fish fixed in $4 \%$ formalin varies depending on the size of the fish. They therefore conclude that in the case of fish which weighed less than $200 \mathrm{~g}$ in the fresh state, it is essential to reduce the value obtained after fixing by $6-8 \%$.

The aim of the present report was: (a) to compare the effect of fixing in alcohol and formalin on the weight of some internal organs in Micromammalia; (b) to determine whether the length of the period during which they are kept in the fixing fluid, and also procedure after fixing, affects weight changes in the organs; (c) to determine whether the kind of fixing fluid affects the weight of the dry remains.

\section{MATERIAL AND METHODS}

Sixty individuals of Mus musculus Linnaeus, 1758, 60 of Clethrionomys glareolus (S chreber, 1780) and 40 of Microtus agrestis ( $\mathrm{Linnaeus,1761)}$ ) were used for the experiments, proceeding as follows: the animals were anaesthetized with ether pro narcosi and then dissected. The internal organs: brain, heart, spleen, liver and kidneys were first rinsed in saline solution and the excess fluid dried on blotting paper, then weighed and fixed: A - immediately in $90 \%$ ethyl alcohol, $\mathrm{B}-$ in alcohol at increasing concentration, starting with 70 , through 80,85 to $90 \%$, and $\mathrm{C}$ - in $4 \%$ formalin.

The weight of the organs was checked every month, keeping them in the same fixing fluid during the intervals between weighings. This procedure was repeated three times. Before each weighing the organs fixed in alcohol were transferred from the fixing fluid to distilled water and rinsed to avoid evaporation, and in consequence greater changes in weight during weighing. Water was changed three times over the 24-hour period. Organs fixed in formalin were treated in the same way. In the final stage of the experiments all the organs were dried out in a vacuum drier at a temperature of about $18^{\circ} \mathrm{C}$, using $\mathrm{CaCl}_{2}$ as water absorber. The percentage of loss or increase in weight of the various organs was calculated in relation to fresh mass, while the dry residue was also determined in percentages of dry mass.

The differences were tested for singnificance by the Student test, comparing two dependent means (fixation in alcohol). The effect of fixing in formalin on the weight of organs was also checked by the Young von Nauman test. 


\section{RESULTS}

\section{Fixing in alcohol}

A) All the internal organs of 30 individuals of $M$. musculus, fixed in $90 \%$ ethyl alcohol behave similarly and lose in weight as the result of fixation (Fig. 1). The percentage by which weight is reduced is not constant after successive changes of alhocol or uniform for the various organs. For instance in the case of the brain the mean percentage of loss after basic fixing is $21 \%$, and after the third change of alcohol $-42 \%$

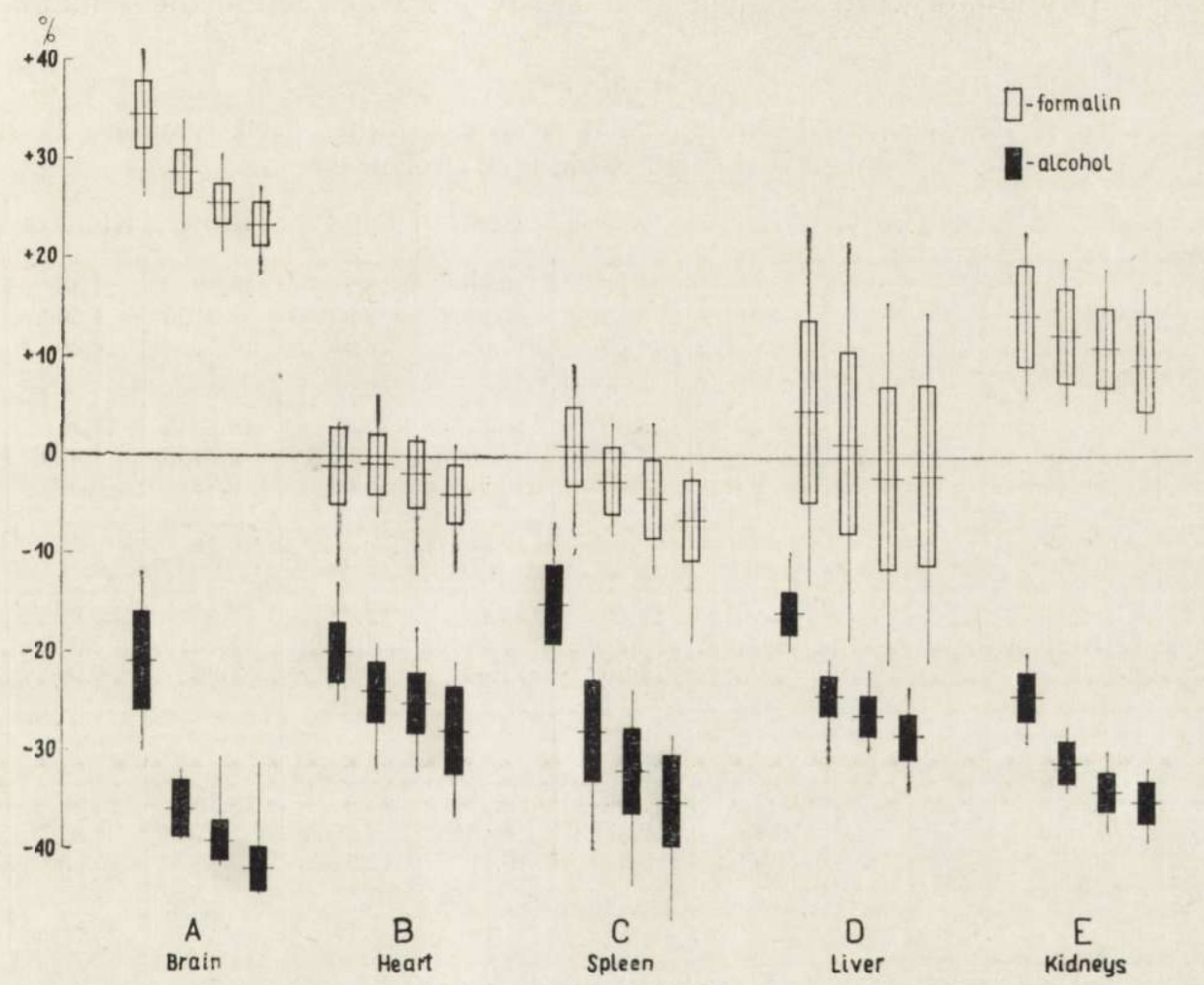

Fig. 1. Changes in weight of internal organs due to fixing in alcohol and formalin expressed in per cent of fresh mass.

Observed ranges, means, and standard deviations are shown.

in relation to the fresh organ. The greatest weight losses of fixed organs usually take place after the basic fixing and after the first change of alcohol $(15-24 \%$ and $24-35 \%)$. Particularly great losses are observed after the first change in the case of the brain and spleen.The other organs exhibit smaller weight losses, and successive changes of alcohol cause a smaller but nevertheless significant weight decrease (Table 1). 
In the final phase this decrease is more balanced for all the organs. The considerable individual variations in percentage of weight loss of different organs is noteworthy. At the same time the coefficient of variation exhibits a general tendency to reduction after successive changes of the fixing fluid (Table 1).

B) The internal organs of 60 individuals of $C$. glareolus were fixed in ethyl alcohol at increasing concentrations (70-90\%). It was found that this procedure does not affect the loss of weight by the organs as the result of fixing. The material was divided into two groups. The organs of 30 individuals were weighed at monthly intervals, while the remain-

Table 1.

Losses in weight of organs in $\%$ of fresh mass, after basic fixation and successive changes of alcohol.

\begin{tabular}{|c|c|c|c|c|c|c|c|}
\hline & \multicolumn{2}{|c|}{ Organ } & Brain & Heart & Spleen & Liver & Kidneys \\
\hline 1 & Fixation & $\begin{array}{c}\overline{\mathrm{x}} \\
\mathrm{SD} \\
\mathrm{V}\end{array}$ & $\begin{array}{l}21.23 \\
5.2287 \\
24.63\end{array}$ & $\begin{array}{l}19.80 \\
3.1015 \\
15.66\end{array}$ & $\begin{array}{l}15.34 \\
39389 \\
25.68\end{array}$ & $\begin{array}{l}15.92 \\
2.3120 \\
14.52\end{array}$ & $\begin{array}{l}24.35 \\
1.5085 \\
6.20\end{array}$ \\
\hline 2 & 1st change & $\begin{array}{l}\bar{x} \\
\text { SD } \\
\text { V }\end{array}$ & $\begin{array}{l}35.90 \\
2.4569 \\
6.84\end{array}$ & $\begin{array}{l}24.37 \\
2.4985 \\
10.25\end{array}$ & $\begin{array}{l}27.87 \\
4.6352 \\
16.63\end{array}$ & $\begin{array}{l}24.36 \\
2.2159 \\
9.09\end{array}$ & $\begin{array}{l}31.21 \\
1.8201 \\
5.38\end{array}$ \\
\hline 3 & \multicolumn{2}{|c|}{ Difference $1-2$} & + & + & + & + & + \\
\hline 4 & 2nd change & $\begin{array}{c}\text { x } \\
\text { SD } \\
\text { V }\end{array}$ & $\begin{array}{l}39.45 \\
2.2103 \\
5.60\end{array}$ & $\begin{array}{c}25.48 \\
3.4066 \\
13.40\end{array}$ & $\begin{array}{l}32.23 \\
4.2159 \\
13.08\end{array}$ & $\begin{array}{l}26.65 \\
2.1215 \\
7.96\end{array}$ & $\begin{array}{l}33.69 \\
2.0519 \\
6.09\end{array}$ \\
\hline 5 & \multicolumn{2}{|c|}{ Difference $2-4$} & + & - & + & + & + \\
\hline 6 & 3rd change & $\begin{array}{c}\overline{\mathrm{x}} \\
\mathrm{SD} \\
\mathrm{V}\end{array}$ & $\begin{array}{l}41.76 \\
2.3156 \\
5.54\end{array}$ & $\begin{array}{l}28.22 \\
4.4345 \\
15.71\end{array}$ & $\begin{array}{l}34.84 \\
4.6057 \\
13.22\end{array}$ & $\begin{array}{l}28.39 \\
2.3787 \\
8.38\end{array}$ & $\begin{array}{l}35.29 \\
1.9961 \\
5.66\end{array}$ \\
\hline 7 & \multicolumn{2}{|c|}{ Difference $4-6$} & + & + & + & + & + \\
\hline
\end{tabular}

+ Significant difference, - Non-significant difference.

ing 30 were placed in fixing fluid for 19 months in order to ascertain to what degree the length of the fixing period without changing the fixing fluid affects changes in their weight. Comparison of the two groups showed that weight losses are greater when the organs are kept for a longer period in alcohol. Changing of the fixing fluid at the end of this period causes further decrease in the weight of the fixed organ, but these differences are greater after fixing for 1 month than after fixing for 19 months (Table 2). 


\section{Fixing in formalin}

The organs of 30 individuals of $M$. musculus were fixed in $4 \%$ formalin. Two groups can be distinguished here: I - organs which markedly increase in weight and II - partly increase and partly decrease in weight (Fig. 1).

The brain increase its weight by an average of $34 \%$ in relation to the fresh mass as the result of fixing and keeping in formalin. After changing the formalin three times over the course of 4 months, these values gradually decrease to $23 \%$ (Fig. 1). Similar changes take place in the kidneys, but their extent is far more limited (14 and $9 \%$ ). These differences proved to be statistically significant when checked with the $t$ Student test.

Table 2.

Effect of changing the fixing fluid on weight losses of organs (expressed in per cent of fresh mass) for different periods.

\begin{tabular}{|c|c|c|c|c|c|c|}
\hline \multirow{2}{*}{ Organ } & \multicolumn{3}{|c|}{19 months fixation } & \multicolumn{3}{|c|}{1 month fixation } \\
\hline & $\overline{\mathrm{x}}$ & $\mathrm{SD}$ & V & $\overline{\mathrm{x}}$ & $\mathrm{SD}$ & V \\
\hline Heart & 36.4 & 4.7245 & 12.98 & 22.4 & 7.6792 & 34.38 \\
\hline Spleen & 27.8 & 7.8715 & 28.31 & 20.0 & 15.6530 & 78.26 \\
\hline Liver & 32.7 & 4.3540 & 13.31 & 16.9 & 7.0690 & 41.83 \\
\hline Kidneys & 28.8 & 2.2271 & 7.73 & 12.6 & 7.3594 & 32.56 \\
\hline \multicolumn{7}{|c|}{ Change of alcohol } \\
\hline Heart & 31.2 & 5.625 & 18.03 & 25.6 & 11.354 & 44.35 \\
\hline Spleen & 36.6 & 7.405 & 20.23 & 30.8 & 12.502 & 40.59 \\
\hline Liver & 36.3 & 4.176 & 1150 & 21.9 & 6.645 & 30.34 \\
\hline Kidneys & 33.3 & 4.436 & 13.32 & 28.6 & 6.270 & 21.92 \\
\hline
\end{tabular}

The heart, spleen and liver in some individuals increase, but decrease in others. The spleen and liver exhibit during the first phase of fixing an average slight weight increase (liver by about $4 \%$, spleen by $1 \%$ ), then a gradual decrease below the value of the fresh mass (Fig. 1). Comparison of average values by the Young v. Nauman test shows that both these organs significantly lose or increase weight as the result of fixing. In the case of the heart, on the other hand, the average value is generally a minus one as early as the first phase of fixing, in fact this organ is subject to smaller changes as the result of fixing in formalin than all the organs examined. After basic fixing the heart decreases in weight by an average of $1.46 \%$. The first change of fixing fluid reduces its weight by $0.92 \%$, and the next by 2.19 and $3.89 \%$. These differences are not statistically significant (Young v. Nauman test) (Fig. 1). Practically speaking the heart does not therefore exhibit significant changes in weight due to fixing in formalin. 


\section{Effect of rinsing in water}

In order to check whether transferring to water and then rinsing fixed organs effects their weight additional experiments were made using the kidneys of 10 individuals of $M$. agrestis. After being fixed for 6 days in alcohol they were transferred to running water and rinsed for 3 days, weighing them every 24 hours. They were next transferred back to alcohol for a further 6 days, again rinsed and weighed. It was found that rinsing kidneys previously fixed in alcohol does not significantly affect their weight changes, but that each successive change of alcohol affects this. It is probable that other organs behave similarly.

\section{Effect of fixing on dry residue}

Organs of $M$. musculus fixed in $90 \%$ alcohol and $4 \%$ formalin were dried, and the dry residue expressed in percentages of the fresh mass. As can be seen from Fig. 2 the dry residue of organs fixed in formalin

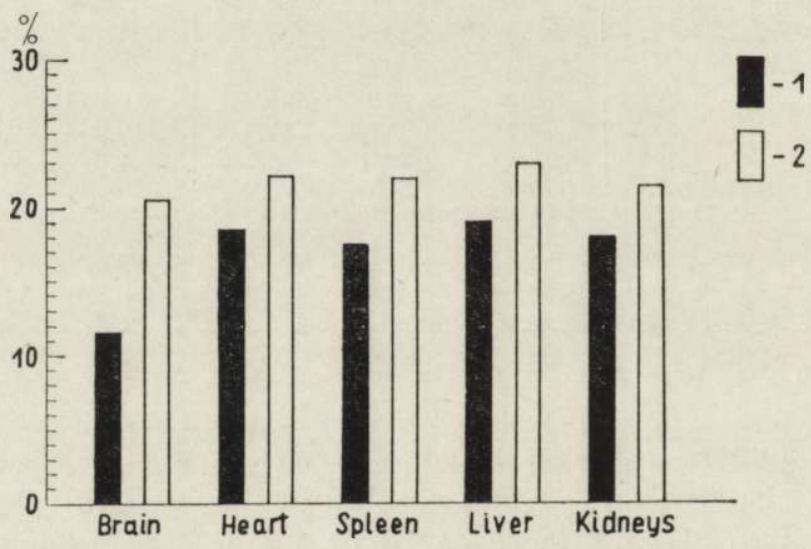

Fig. 2. Dry residue in per cent of fresh mass after fixing in alcohol (1) and formalin (2).

is $20-23 \%$ heavier than that of organs fixed in alcohol. An exception to this is the brain, the dry residue of which after fixing in formalin is almost twice greater than that fixed in alcohol.

\section{DISCUSSION}

It is a generally known fact that fixing in formalin causes an increase, and fixing in alcohol a decrease, in the weight of organs. It is not however possible to determine the extent of these changes. Not only are 
changes of each organ different but even different cells of the same organ may react differently to the fixing fluid, some shrinking and others swelling.

Experiments so far made on the effect of fixing fluid on weight changes have referred to the brain. It was found inter alia that under the influence of formalin and also alcohol the larger the organs the

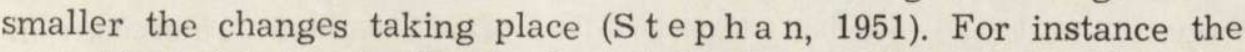
end effect of fixing the brain of a rabbit, dog and sheep in alcohol was $30-40 \%$ loss in weight of the fresh mass. The results of the present experiments show that fixing brains of mammals the size of mice in alcohol also causes a decrease in their weight of about $40 \%$ (almost $42 \%$ ) in the final phase of fixing.

Although the lack of data on the changes of different organs under the influence of fixing in alcohol makes it impossible to compare the results obtained one thing is certain, that each organ exhibits a different degree of changes, and therefore comparison of the reciprocal proportions of their weight after fixing is impossible.

The average weight loss of the brain in alcohol is greatest, i. e. $42 \%$, the kidneys and spleen about $35 \%$, liver and heart over $28 \%$. This is undoubtedly connected with the physical and chemical structure and the function of the different organs.

Confirmation is obtained of the fact observed by $\mathrm{K} \mathrm{lat} \mathrm{t} \mathrm{(1921,} \mathrm{cited}$ after $\mathrm{S}$ te phan, 1951), in respect of the brains of dogs, that successive changes of alcohol cause progressive decrease in weight. This applies to all the organs examined. The greatest losses observed after the first change of alcohol can be explained by the greater amount of water extracted at this time. The following changes of alcohol decrease the weight of different organs to a lesser degree and are undoubtedly connected with the gradual extraction of fats.

The time of fixing is also of importance. When organs are kept for a considerable time in alcohol without its being changed this leads not only to greater extraction of water but also washing out and dissolving fatty compounds, which is shown by the increased losses (cf. Table 2). These processes were not yet completed during the 4 months the organs were kept in alcohol, as shown by the lack of stability in their weights. Successive changes of alcohol do in fact cause slight but significant and progressive decrease in the weight of the organs.

In the end the method of fixing in alcohol - directly in $90 \%$ or gradually in alcohols of increasing concentration does not significantly affect the final result.

$\mathrm{S}$ te phan (1951) draws attention to the fact that when the brain of animals is fixed in formalin the weight of the organ increases progress- 
ively during the first week of fixing and after reaching a certain maximum after $2-5$ days it decreases, and after 2-3 months may reach a \pm constant value, greater by $1.5-8 \%$ than that of the fresh mass. These weights may continue to fall even below the value of the fresh mass, particularly when kept for a long time in formalin. The results obtained in this study in respect of the brains of Micromammalia do not confirm these observations. The brain decidedly increases in weight and despite the fact that certain tendencies are apparent to reduction in mass increase during the first phase of fixing, this never proceeds as far as reducing the weight below the value of the fresh mass. The weight of brains which have been kept for 4 months in formalin, that is, a period sufficient to reach an approximately constant mass, remains $20 \%$ heavier when compared with values for fresh brains. It is possible that such great changes are connected with the small dimensions of these organs.

In many individuals organs such as the heart, spleen or liver do not increase in weight during the first phase of fixing, in fact quite the opposite, as reduction in weight takes place (Fig. 1). This state was maintained for the full 4-month period of the experiments. The reasons for this should probably be scught for not in the extremely different effect exerted by the fixing fluid on the organs, but in the internal structure and biochemical composition of the latter.

This great variability in the weight of organs fixed in either alcohol or formalin raises the question as to whether material of this kind can be used for weight measurements. The inexactitude of such measurements is great and this problem has already been discussed in literature (P u c e k, 1965).

The results of the experiments presented show that the weight of fixed internal organs is burdened with considerable and variable error, depending on the kind of fixing fluid and treatment of material after fixing. Thus only in limited cases, when the homogeneity of the material is fully maintained with regard to the kind of fixing fluid, number of times the fluid is changed, time of fixing and treatment after fixing, it is possible to assume that the weights of fixed organs remain in direct relation to their fresh mass. Where there is no such guarantee it is impossible to take the results cbtained from elaboration of fixed materials as a basis.

\section{REFERENCES}

1. Ketz H. A., 1952/53: Beitrag zur Anatomie und Histologie des Kleinhirns der Schweines mit Gewichsmessungen am Gesamthirn. Wiss. Z. Humboldt-Univ., Mat.-naturwis., 5: 91-101. 
2. Kosty r a J., 1960: Pomiary wagowe ośrodkowego układu nerwowego w rozwoju embrionalnym bydła. Annls Univ. M. Curie-Skłodowska, DD, 13 (1958), 10: $141-170$.

3. Lusk S. \& Pokorny J., 1964: Zmeny váhy a nekterých rozmeru u ryb vlivem konservace ve 4\% roztoku formaldehydu. Zool. Listy, 13, 2: 135-142.

4. Pucek Z., 1965: Seasonal and age changes in the weight of internal organs of shrews. Acta theriol., 10, 26: 369-438.

5. Stephan H., 1951: Vergleichende Untersuchungen über den Feinbau des Hirnes von Wild und der Haustieren. (Nach Studien am Schweim und Schaf) Zool. Jb. (Syst.), 71, 4: 487-586.

6. Webster S. H. \& Liljegren E. J., 1949: Body weight ratios for certain organs of laboratory animals. II. Guinea pig. Am. J. Anat., 85, 2: 199-230.

Received, June 9, 1967.

Polish Academy of Sciences, Mammals Research Institute, Białowieża, Poland.

\section{Michalina PUCEK}

\section{ZMIANY CIĘŻARU NIEKTORYCH NARZĄDÓW WEWNĘTRZNYCH MAEYCH SSAKOW POD WPEYWEM UTRWALANIA}

\section{Streszczenie}

Utrwalanie w alkoholu narządów wewnętrznych małych ssaków powoduje zmniejszenie ich ciężaru. Mózg średnio traci $42 \%$, nerki i śledziona $35 \%$, wątroba i serce ponad $28 \%$ (Ryc. 1 , Tabela 1 ).

Zmniejszanie się ciężaru poszezególnych narządów jest związane z długością utrwalania i ilością zmian utrwalacza (Tabela 2).

Wpływ 4\% formaliny na narządy jest różny. Mózg i nerki zdecydowanie powiększają swój ciężar w pierwszej fazie utrwalania. Potem przyrost ten zmniejsza się, lecz nigdy nie spada poniżej ciężaru świeżej masy, jak to obserwujemy w przypadku śledziony czy wątroby. Serce natomiast nie wykazuje istotnych zmian w ciężarze (Ryc. 1).

Duża zmienność ciężaru narządów utrwalanych w alkoholu i formalinie uniemożliwia wykorzystywanie takich materiałów do opracowywania zmian ciężaru i wagowych proporcji narządów wewnętrznych. 